\title{
Social Support and Affective Commitment: Mediation Mechanisms of Relational Attachment
}

\author{
Haznil Zainal ${ }^{a}$, Dewi Atmi Dilla ${ }^{a, *}$ \\ ${ }^{a}$ Magister of Management, Postgraduate Program, Universitas Lancang Kuning, Indonesia.
}

\begin{abstract}
This study aims to determine whether social support has an effect on affective commitment and whether relational attachmen is able to mediate the relationship between social support and affective commitment to employees. Sources of data in this paper are primary data. With 99 employees as the writing sample. Analysis of the data used in this paper is PLS Structural Equation Modeling (SEM) which is operated through the SmartPLS program. The results showed that social support had a positive and significant effect on relational engagement, relational attachment had a positive and significant effect on affective commitment, and relational attachment was able to mediate social relationships support affective commitmen.
\end{abstract}

ARTICLE HISTORY

Accepted: December 31, 2021

KEYWORDS

Social Support. Affective Commitment, Relational Attachment Mediation Mechanism

\section{Introduction}

In social life, human relations are reflected in the interaction of the individual activities of the community. Interaction in society is related to social interaction. This interaction occurs through two things, namely social contact and communication. Social contact can take place in three forms, namely, individual, between individuals with groups and between groups. While communication is a person giving meaning to the behavior of others. This relationship or interaction is also called relational. To form good public relations is strongly influenced by relational attachment. Just as in society, relational also occurs in an organization.

Organizations cannot carry out their activities without human resources. Human resources are very important in the organization, because the effectiveness and success of the organization is highly dependent on the quality and performance of the existing human resources in the organization. Research has proven that the quality of work of members of the organization is largely determined by how strong the commitment of its members to the organization.

By having members who have a strong commitment, the organization or other agencies already have very expensive assets, which cannot be valued in money. What needs to be done in realizing good organizational goals is to provide a comfortable work environment and increase positive relationship attachments for each employee. This is because this step is the first step to produce organizational members who have a strong affective commitment. " CORRESPONDING AUTHOR. Email:gravitasi@gmail.com. 
Affective commitment is an individual's willingness to stay in the organization which is marked by an emotional attachment to the organization, identification of the values and goals of the organization, and involvement in the organization (Christa, 2013). Affective commitment is also more valuable for an organization because it involves emotional factors so that employees will work with feelings of pleasure and enjoy their role in the company (Armanu dan Mandayanti, 2011). Thus, research investigating the mechanism of increasing affective commitment of organizational members is urgently needed in the field of management and organization studies as well as in a practical perspective.

\section{Theoretical support}

\section{Relational System Theory}

The concept of relational attachment Kahn (2007) reflects employees' affective feelings about closeness and relationships with others at work, and, as such, is linked to other constructs that reflect high-quality working relationships. For example, relational engagement is conceptually related to interpersonal trust, which involves close emotional attachment, and concern for one's partner (McAllister, 1995).

\section{Social Support}

Social support generally describes the role or influence that can be caused by other meaningful people such as family, friends, relatives, and co-workers. According to Brownel and Shumaker (Sulistyawati, 2010; Rima and Raudatussalamah, 2012) There is an indirect effect of social support means that social support affects individual well-being by reducing the severity of the stress of an event. Social support involves meaningful social relationships, so that it can have a positive influence on the recipient.

\section{Affective Commitment}

Organizational affective commitment can have a positive impact on problems of working conditions for employees, among others, by reducing work pressure by suppressing burnout or emotional exhaustion (Schmidt, 2007). In addition, another positive impact is lowering the risk of resignation (Meyer, Stanley, Herscovitch, and Topolnytsky, 2002), reduce employee absenteeism (Eisenberger, Fasolo, dan Davis-LaMastro, 1990), individuals can appreciate company values (Beheshtifar and Herat, 2013), and adhere to organizational policy norms and practices (Jena, Bhattacharyya, and Pradhan, 2017). Practically, individuals with organizational affective commitment will work hard and perform better (Meyer and Allen, 1997). Furthermore, organizational affective commitment is also thought to be influenced by age (Pourghaz, Tamini, and Karamad, 2011). Some researchers suggest that demographic factors such as age and length of work also influence organizational commitment (Azeem, 2010; Cohen, 1993; Meyer and Allen, 1990). In addition, other factors that can affect organizational affective commitment are perceived organizational support (POS) (Eisenberger et al., 1990; Eisenberger, Huntington, Hutchison, and Sowa, 1986; Meyer and Allen, 1997; 
Rhoades et al., 2001). Perceived organizational support is defined as an individual's belief that the organization appreciates the work and shows concern for the welfare of employees (Eisenberger et al., 1986).

\section{Relational Attachment}

According to Ruben and Stewart (2006) interpersonal relationships are relationships based on reciprocal message processing. A relationship is formed when there is reciprocal message processing. Meanwhile, according to Spradley and Mccurdy (1972), relationships or relationships that occur between individuals that last for a relatively long time will form a pattern, this relationship pattern is also called a relationship pattern.

\section{Research method}

\section{Data Analysis}

This research is included in the type of explanatory study research. This study aims to provide an explanation of the impact of social support on affective commitment. Furthermore, this study further explains the mechanism of relational attachment that mediates the relationship between social support and affective commitment. It can also be said that this research is an explanatory research that uses quantitative methods to test hypotheses empirically. Research conducted in The Agency of Public Works dan Penataan Ruang, Perumahan dan Kawasan Permukiman (DPUPRPKP) Meranti Islands Regency. In testing the hypothesis, the research uses primary data. This study seeks to obtain data by sending questionnaires to employees who work in one of the government agencies in the Meranti Islands Regency by utilizing selfadministered questionnaire. The distribution of the questionnaire will be carried out by convenience sampling method.

\section{Results}

\section{Analisis SEM-PLS}

Data analysis in this study tested the effect of several independent variables on the dependent variable and the moderating variable. Hypothesis testing is done by using the method Partial Least Square (PLS). Partial Least Square is the solution method structural Equation Modelling (SEM). Research entitled the effect of social support on Affective Commitment with relational attachment as a mediation on employees the Agency of Public Works and Spatial Planning, Housing and Settlement Areas of the Meranti Islands Regency. In analyzing research data using SEM analysis with the application WarpPLS 6.0.

Inner model is an analysis carried out to test research hypotheses and answer the problems posed. Hypothesis testing is carried out according to the research framework carried out to analyze and test directly and indirectly between exogenous and endogenous variables with a moderation model. The significance level of testing this hypothesis is done by looking at the value of the p-value. 


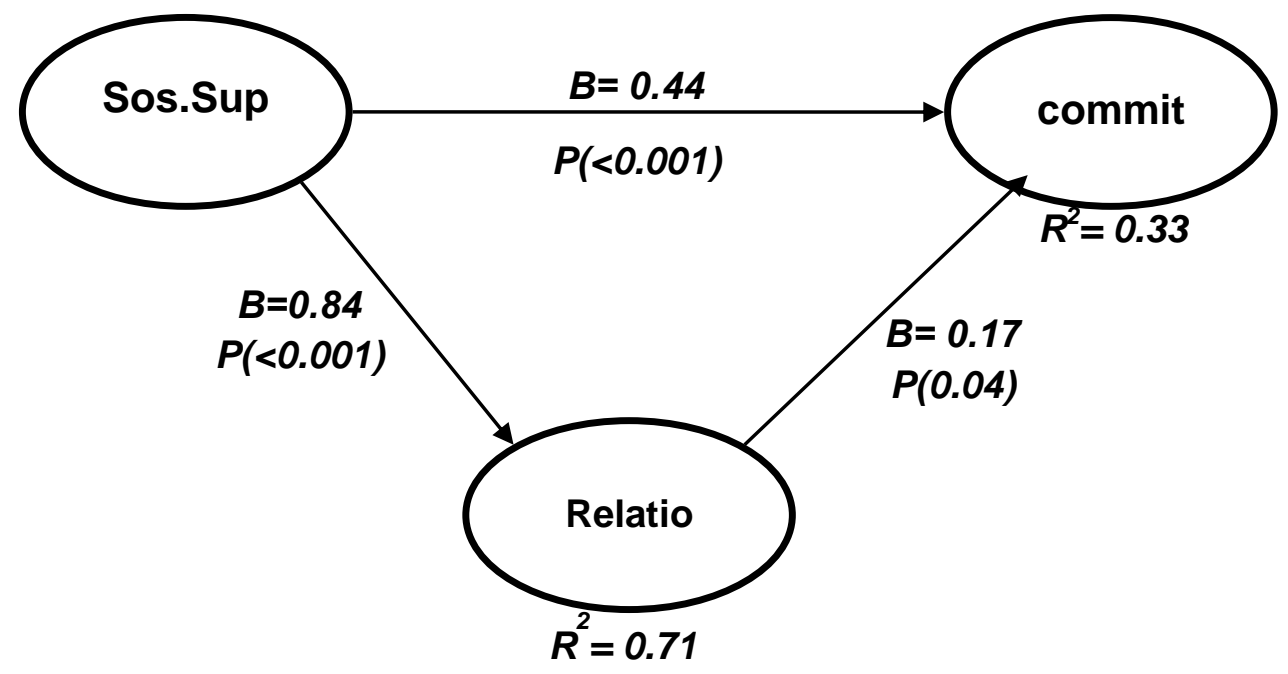

Figure 1. Structural Equation

Figure 1 shows the path coefficient results with a significance level in accordance with the calculations that have been carried out using Warp PLS.

\section{Discussions}

\section{The Effect of Social Support on Affective Commitment}

Calculation of the influence of the Social Support variable has a positive effect on Affective Commitment. In this calculation, the path coefficient value is 0.436 with a significance level or p-value $<0.001$. The calculation explains that the hypothesis of Social Support has a positive effect on Acceptable Affective Commitment and the relationship is positive. This means that directly Social Support (X) has a significant effect on Affective Commitment (Y), the higher the employee's Social Support, the higher the Affective Commitment or vice versa.

\section{The Effect of Social Support on Relational Attachment}

Calculation of the influence of the Social Support variable has a positive effect on Relational Engagement. In this calculation, the path coefficient value is 0.841 with a significance level or p-value $<0.001$. The calculation explains that the hypothesis of Social Support has a positive effect on Relational Engagement is accepted and the relationship is positive. This means that directly Social Support (X) has a significant effect on Relational Engagement (Z), the higher the employee's Social Support, the lower the Relational Engagement or vice versa.

\section{The Effect of Relational Attachment on Affective Commitment}

Calculation of the influence of the Relational Attachment variable has a positive effect on Affective Commitment. In this calculation, the path coefficient value is 0.169 with a significance level or p-value of 0.041. The calculation explains that the Relational Attachment hypothesis has a positive effect on Acceptable Affective Commitment and the relationship is positive. This means that Relational Engagement $(Z)$ has a significant effect on Affective 
Commitment (Y), the higher the Employee's Relationship Engagement, the higher the Affective Commitment or vice versa.

\section{Relational Attachment Mediates the relationship of Social Support with Affective Commitment}

Calculation of the influence of the Relational Attachment variable as a mediating variable of Social Support on affective commitment. In this calculation, the path coefficient value is 0.142 with a significance level of 0.02 or $p$-value $=0.02$. The calculation explains that the relational attachment hypothesis as a variable that mediates Social Support on affective commitment is accepted. This means that Relational Attachment indirectly as a mediating variable of Social Support on affective commitment, this shows the role of Relational Attachment has an effect on these two variable relationships, where the greater the size of the relationship, the lower the social support in the workplace so that it has an impact on the high Affective Commitment.

\section{Conclusion}

Social Support has a positive and significant effect on Affective Commitment to employees at The Agency of Public Works and Spatial Planning, Housing and Settlement Areas (DPUPRPKP) Meranti Islands Regency. Social Support has a positive and significant effect on relational attachment to workers in The Agency of Public Works and Spatial Planning, Housing and Settlement Areas (DPUPRPKP) Meranti Islands Regency. Relational attachment has a positive and significant effect on affective commitment to workers in The Agency of Public Works and Spatial Planning, Housing and Settlement Areas (DPUPRPKP) Meranti Islands Regency. Relational attachment is able to mediate Social Support for Affective Commitment to workers in The Agency of Public Works and Spatial Planning, Housing and Settlement Areas (DPUPRPKP) Meranti Islands Regency. From the results of questionnaires that have been distributed to 99 employees at The Agency of Public Works and Spatial Planning, Housing and Settlement Areas (DPUPRPKP) Meranti Islands Regency, it is hoped that the results of this study will provide information for the secretariat in managing employees, that the importance of social support received by employees thus forming affective commitment through the mediating mechanism of relational attachment.

\section{Acknowledgement}

We thank the anonymous reviewers for their valuable support and guidance in improving the quality of the paper. Furthermore, we thank to Adi Rahmat and Muhammad Rasyid Abdillah for his feedback on earlier versions of the paper. Besides, we also thank Universitas Lancang Kuning, Indonesia, for their assistance and support along the undertaken of this research.

\section{Disclosure statement}

No potential conflict of interest was reported by the authors. 


\section{References}

Abdillah, M. R. C. T., (2020). Metode Penelitian: Perspektif Sains Organisasi. UNILAK PRESS

Allen, N. J., and Meyer, J. P. (1990). The measurement and antecedents of affective, continuance and normative commitment to the organization. Journal of occupational psychology, 63(1), 1-18.

Allen, N.J. and Meyer, J.P. 1991. A Three-Component Conceptualization of Organizational Commitment, Human Resource Management Review, Vol 1, No 1, pp. 61-89.

Ariyabuddhiphongs, V., and Kahn, S. I. (2017). Transformational leadership and turnover intention: The mediating effects of trust and job performance on café employees in Thailand. Journal of Human Resources in Hospitality and Tourism, 16(2), 215-233.

Armanu Fatchur Rohman dan Mandayanti. 2011. Pengaruh pemberdayaan psikologi dan komitmen afektif terhadap kepuasan kerja dan kinerja pegawai. Jurnal Aplikasi manajemen Vol. 1 No. 1. ISSN :1693341.

Armanu, F.R dan Mandayanti. 2012. Pengaruh Pemberdayaan Psikologis dan Komitmen Afektif terhadap Kepuasan Kerja dan Kinerja pegawai (Studi pada Dinas Tata Kota dan Pengawasan Bangunan Kota Mataram), Jurnal Aplikasi Manajemen ISSN :1693-5241 Vol.10(1):152-160.

Azeem, Syed Mohammad. 2010. "Job Satisfaction and Organizational Commitment among Employees in the Sultanate of Oman”. Journal Psychology, Vol. 1. p. 295-299.

Bakker, A. B., and Schaufeli, W. B. (2015). Work engagement. Wiley encyclopedia of management, 1-5.

Blau, P. M. (1964). Justice in social exchange. Sociological inquiry, 34(2), 193-206.

Blau, P. M. (1964). Exchange and power in social life. New York, NY: John Wiley and Sons.

Bloemer, J., Pluymaekers, M., and Odekerken, A. (2013). Trust and affective commitment as energizing forces for export performance. International Business Review, 22(2), 363-380.

Bourque, L., and Fielder, E. P. (2003). How to conduct self-administered and mail surveys (Vol. 3). Sage.

Brislin, R. W. (1970). Back-translation for cross-cultural research. Journal of cross-cultural psychology, 1(3), 185216.

Brislin, R. W. (1980). Translation and content analysis of oral and written materials. Methodology, 389-444.

Brotheridge, C. M., and Lee, R. T. (2002). Testing a conservation of resources model of the dynamics of emotional labor. Journal of occupational health psychology, 7(1), 57.

Cable, D. M., and Edwards, J. R. 2004. Complementary and supplementary fit: A theoretical and empirical integration. Journal of Applied Psychology, 89: 822- 834.

Caplan, R. D. (1987). Person-environment fit theory and organizations: Commensurate dimensions, time perspectives, and mechanisms. Journal of Vocational behavior, 31(3), 248-267.

Caplan, R. D., and Van Harrison, R. (1993). Person-environment fit theory: Some history, recent developments, and future directions.

Castanheira, J. M., and Marques, C. A. (2015). Convectively coupled equatorial-wave diagnosis using threedimensional normal modes. Quarterly Journal of the Royal Meteorological Society, 141(692), 27762792.

Castanheira, F. (2016). Perceived social impact, social worth, and job performance: Mediation by motivation. Journal of Organizational Behavior, 37(6), 789-803.

Chiaburu, D. S., and Harrison, D. A. (2008). Do peers make the place? Conceptual synthesis and meta-analysis of coworker effects on perceptions, attitudes, OCBs, and performance. Journal of applied psychology, 93(5), 1082.

Chiaburu, D. S., and Harrison, D. A. (2008). Do coworkers make the place? Conceptual synthesis and metaanalysis of lateral social influences in organizations. Journal of Applied Psychology, 93(5), 1082-1103.

Cohen, J. A. (1993). Caring perspectives in nursing education: liberation, transformation and meaning. Journal of Advanced Nursing, 18(4), 621-626.

Cropanzano, R., and Mitchell, M. S. (2005). Social exchange theory: An interdisciplinary review. Journal of management, 31(6), 874-900.

Crider, A.B. 1983. Psychology. Scott, Foresman and Company 
Cropanzano, R., and Mitchell, M. S. (2005). Social exchange theory: An interdisciplinary review. Journal of management, 31(6), 874-900.

Diamond, M. A. (1986). Resistance to change: A psychoanalytic critique of Argyris and Schon's contributions to organization theory and intervention. Journal of Management Studies, 23(5), 543-562.

Dutton, J. E., and Ragins, B. R. (Eds.). (2017). Exploring positive relationships at work: Building a theoretical and research foundation. Psychology Press.

Ehrhardt, K., and Ragins, B. R. (2019). Relational attachment at work: A complementary fit perspective on the role of relationships in organizational life. Academy of Management Journal, 62(1), 248-282.

Eisenberger, R., Huntington, R., Hutchison, S., and Sowa, D. (1986). Perceived organizational support. Journal of Applied psychology, 71(3), 500.

Eisenberger, R., Fasolo, P., and Davis-LaMastro, V. (1990). Perceived organizational support and employee diligence, commitment, and innovation. Journal of applied psychology, 75(1), 51.

Fazio, J, Gong, B, Sims, R., Yurova, Y. (2017). The role of affective commitment in the relationship between social support and turnover intention. Management Decision. 55 (3), pp.512-525, https://doi.org/10.1108/MD-05-2016-0338

Fink, A. (2003). The survey handbook. sage.

Gautam, T., Van Dick, R., and Wagner, U. (2004). Organizational identification and organizational commitment: Distinct aspects of two related concepts. Asian Journal of social psychology, 7(3), 301315 .

Gardner, K. A., and Cutrona, C. E. (2004). Social support communication in families.

Goldhaber, G. M., Porter, D. T., Yates, M. P., and Lesniak, R. (1978). Organizational communication: 1978. Human Communication Research, 5(1), 76-96.

Giao, Bui Nhat Vuong and Hasanuzzaman Tushar. (2020). The impact of social support on job-related behaviors through the mediating role of job stress and the moderating role of locus of control: Empirical evidence from the Vietnamese banking industry, Cogent Business and Management, 7:1, 1841359, DOI: $10.1080 / 23311975.2020 .1841359$

Grant, A. M. (2007). Relational job design and the motivation to make a prosocial difference. Academy of management review, 32(2), 393-417.

Gutek, B. A. (1999). The social psychology of service interactions. Journal of Social Issues, 55(3), 603-617.

Hair Jr, J. F., Sarstedt, M., Hopkins, L., and Kuppelwieser, V. G. (2014). Partial least squares structural equation modeling (PLS-SEM): An emerging tool in business research. European business review.

Hartmann, L. C., and Bambacas, M. (2000). Organizational commitment: A multi method scale analysis and test of effects. The International Journal of Organizational Analysis.

Homburg, C., and Stock, R. M. (2005). Exploring the conditions under which salesperson work satisfaction can lead to customer satisfaction. Psychology and Marketing, 22(5), 393-420.

Hutchison, S. (1997). A path model of perceived organizational support. Journal of Social Behavior and Personality, 12(1), 159.

Isnawati, D., and Suhariadi, F. (2013). Hubungan antara dukungan sosial dengan penyesuaian diri masa persiapan pensiun pada karyawan PT pupuk kaltim. Jurnal Psikologi Industri dan Organisasi, 1(3), $172-177$.

Jena, L. K., Bhattacharyya, P., and Pradhan, S. (2017). Employee engagement and affective organizational commitment: Mediating role of employee voice among Indian service sector employees. Vision, 21(4), 356-366.

Kahn, W. 1998. Relational systems at work. In B. M. Staw and L. L. Cummings (Eds.), Research in organizational behavior: 39-76. Greenwich, CT: JAI Press.

Kahn, W. 2007. Meaningful connections: Positive relationships and attachments at work. In J. E. Dutton and B. R. Ragins (Eds.), Exploring positive relationships at work: Building a theoretical and research foundation: 189-206. New York, NY: Routledge. 
Kahn, B. E. (1998). Dynamic relationships with customers: High-variety strategies. Journal of the Academy of Marketing Science, 26(1), 45-53.

Kim, H. S., Sherman, D. K., and Taylor, S. E. (2008). Culture and social support. American psychologist, 63(6), 518.

Komansilan, A., Abadi, A. L., Yanuwiadi, B., and Kaligis, D. A. (2012). Isolation and identification of biolarvicide from soursop (Annona muricata Linn) seeds to mosquito (Aedes aegypti) larvae. Int J Eng Technol, $12(03), 28-32$.

Kozlowski, S. W., and Klein, K. J. (2000). A multilevel approach to theory and research in organizations: Contextual, temporal, and emergent processes.

Maslihah, S. (2011). Studi tentang hubungan dukungan sosial, penyesuaian sosial di lingkungan sekolah dan prestasi akademik siswa SMPIT Assyfa Boarding School Subang Jawa Barat. Jurnal Psikologi, 10(2), 103-114.

McAllister, D. J. (1995). Affect-and cognition-based trust as foundations for interpersonal cooperation in organizations. Academy of management journal, 38(1), 24-59.

Melati, R., and Raudatussalamah, R. (2012). Hubungan Dukungan Sosial Suami Dengan Motivasi Dalam Menjaga Kesehatan Selama Kehamilan. Jurnal Psikologi, 8(2), 111-118.

Meilianawati. (2015). Hubungan antara dukungan sosial orang tua dengan minat melanjutkan pendidikan perguruan tinggi pada remaja di kecamatan keluang musi banyuasin. Jurnal Fakultas Psikologi Universitas Bina Darma, Palembang.

Methot, J. R., Melwani, S., and Rothman, N. B. (2017). The space between us: A social-functional emotions view of ambivalent and indifferent workplace relationships. Journal of Management, 43(6), 1789-1819.

Mercurio, Z. A. (2015). Affective commitment as a core essence of organizational commitment: An integrative literature review. Human Resource Development Review, 14(4), 389-414.

Meyer, J. P., Stanley, D. J., Herscovitch, L., and Topolnytsky, L. (2002). Affective, continuance, and normative commitment to the organization: A meta-analysis of antecedents, correlates, and consequences. Journal of vocational behavior, 61(1), 20-52.

Meyer, J. P., and Allen, N. J. (1997). Commitment in the workplace: Theory, research, and application. Sage publications.

Meyer, J. P., Allen, N. J., and Smith, C. A. (1993). Commitment to organizations and occupations: Extension and test of a three-component conceptualization. Journal of applied psychology, 78(4), 538.

Meyer, J. P., and Allen, N. J. (1987). A longitudinal analysis of the early development and consequences of organizational commitment. Canadian Journal of Behavioural Science/Revue canadienne des sciences du comportement, 19(2), 199.

Montgomery, B. M., and Baxter, L. A. (1998). Dialogism and relational dialectics. Dialectical approaches to studying personal relationships, 155-183.

Muchinsky, P. M., and Monahan, C. J. (1987). What is person-environment congruence? Supplementary versus complementary models of fit. Journal of vocational behavior, 31(3), 268-277.

Neuman, W. L. (2006). Workbook for Neumann Social research methods: qualitative and quantitative approaches. Allyn and Bacon.

Neuman, W.L. (2011) Social Research Methods Qualitative and Quantitative Approaches. 7th Edition, Pearson, Boston.

Neuman, W. L. (2013). Social Research Methods: Qualitative and Quantitatif Approaches (7th editio). PT Indeks.

Neuman, W. L. (2014). Social research methods: Qualitative and quantitative approaches: Pearson new international edition. Pearson Education Limited.

Podsakoff, P. M., MacKenzie, S. B., and Podsakoff, N. P. (2012). Sources of method bias in social science research and recommendations on how to control it. Annual review of psychology, 63, 539-569.

Pourghaz, A., Tamini, K. B., and Karamad, A. (2011). Do demographic characteristics make a difference to job satisfaction, organizational commitment and burnout among travel agency drivers? (A Case Study in Iran). Journal of Basic and Applied Scientific Research, 1(8), 916-923. 
Ragins, B. R., and Button, J. E. (2007). Positive relationships at work: an introduction and invitation.

Rhodes, G., Yoshikawa, S., Clark, A., Lee, K., McKay, R., and Akamatsu, S. (2001). Attractiveness of facial averageness and symmetry in non-Western cultures: In search of biologically based standards of beauty. Perception, 30(5), 611-625.

Rhoades, L., Eisenberger, R., and Armeli, S. (2001). Affective commitment to the organization: the contribution of perceived organizational support. Journal of applied psychology, 86(5), 825.

Rhoades, L., and Eisenberger, R. (2002). Perceived organizational support: a review of the literature. Journal of applied psychology, 87(4), 698.

Rokhimah. (2015). Pengaruh Dukungan Sosial Dan Efikasi Diri Terhadap Minat Melanjutkan Pendidikan Ke Perguruan Tinggi Pada Siswa SMA Negeri 1 Tenggarong Seberang. Jurnal Psikologi ISSN, 3(1), 382394.

Rousseau, V and Aubé. (2010). Social Support at Work and Affective Commitment to the Organization: The Moderating Effect of Job Resource Adequacy and Ambient Conditions, The Journal of Social Psychology, 150:4, 321-340, DOI: 10.1080/00224540903365380

Ruben D Brent and Stewart P Lea, (2006). Communication and Human Behaviour, Pearson.

Santoso, M. D. Y. (2021). DUKUNGAN SOSIAL DALAM SITUASI PANDEMI COVID 19. Jurnal Litbang Sukowati: Media Penelitian dan Pengembangan, 5(1), 11-26.

Sarafino, E. P., Timothy W. Smith. 2011. Health Psychology: Biopsychosocial Interactions, 7th edition. Amerika Serikat: John Wiley and Sons, Inc.

Schaufeli, W. B., and Bakker, A. B. (2004). Job demands, job resources, and their relationship with burnout and engagement: A multi-sample study. Journal of Organizational Behavior: The International Journal of Industrial, Occupational and Organizational Psychology and Behavior, 25(3), 293-315.

Schaufeli, W. B., and Bakker, A. B. (2010). Defining and measuring work engagement: Bringing clarity to the concept. Work engagement: A handbook of essential theory and research, 12, 10-24.

Schaufeli, W. B. (2013). What is engagement. Employee engagement in theory and practice, 15, 321.

Schaufeli, W. B., and Taris, T. W. (2014). A critical review of the job demands-resources model: Implications for improving work and health. Bridging occupational, organizational and public health, 43-68.

Schmidt, S. W. (2007). The relationship between satisfaction with workplace training and overall job satisfaction. Human resource development quarterly, 18(4), 481-498.

Seers, A., McGee, G. W., Serey, T. T., and Graen, G. B. (1983). The interaction of job stress and social support: A strong inference investigation. Academy of management Journal, 26(2), 273-284.

Schoenrade, P. A., Batson, C. D., Brandt, J. R., and Loud, R. E. (1986). Attachment, accountability, and motivation to benefit another not in distress. Journal of Personality and Social Psychology, 51(3), 557.

Shaver, P. R., Collins, N., and Clark, C. L. (1996). Attachment styles and internal working models of self and relationship partners.

Sluss, D. M., and Ashforth, B. E. (2007). Relational identity and identification: Defining ourselves through work relationships. Academy of management review, 32(1), 9-32.

Spradley, J., and McCurdy, D. (1972). The Cultural Experience: Ethnography in Complex Society. Prospect Heights, Illinois.

Suseno, M. N. M. (2010). Pengaruh dukungan sosial dan kepemimpinan transformasional terhadap komitmen organisasi dengan mediator motivasi kerja. Jurnal Psikologi, 37(1), 94-109.

Uchino, B. N. (2004). Social support and physical health: Understanding the health consequences of relationships. Yale university press.

UR Christa U.R, (2013). Peran human capital dan structural capital Dalam meningkatkan kinerja organisasi (suatu kajian konseptual) Jurnal Sains Manajemen Universitas Parahyangan.

Vaux, A. (1988). Social support: Theory, research, and intervention. New York, Praeger publishers.

Vroom, V. H. (1964). Work and motivation.

West, Richard. Lynn H.Turner. 2007. “Pengantar Teori Komunikasi”. Salemba Humanika. Jakarta. 
Dewi Atmi Dilla, Social Support and Affective Commitment ...

Wetzels, M., Odekerken-Schröder, G., and Van Oppen, C. (2009). Using PLS path modeling for assessing hierarchical construct models: Guidelines and empirical illustration. MIS quarterly, 177-195. 